\title{
МОНГОЛ, ЯПОНЫ ХУДАЛДАА, ЭДИЙН ЗАСГИЙН ХАМТЫН АЖИЛЛАГААНЫ ӨНӨӨГИЙН БАЙДАЛ
}

\section{М.Болормаа}

Товч агуулга: ЭнэхүY өгүҮлэлд шинэ мянганы эхэн үе буюу 2000 оноос хойшхп Монгол Японы худалдаа, эдийн засгийн харилиаа, хамтын ажиллагааны өнөөгийн байдльг Хөгжлийн албан ёсны тусламж (ХАЁТ), худалдаа, хөрөнгө оруулалт, Эдийн засгийн түнилэлийн хэлэлиээр (ЕРА)-ийн хүрээнд тоймлон авч Үзэх оролдлого хийлээ.

Tүлхүур үгс: Хөгжлийн албан ёсны тусламж, худалдаа, хөрөнгө оруулалт, Эдийн засгийн түншлэлийн хэлэлиээр

\section{Монгол Улсад ҮзУҮлэс ирсэн Япон улсын тусламжс}

Япон улсын Засгийн газар Хөгжлийн албан ёсны тусламж (ХАЁТ) үзүүлэх орны тоонд Монгол Улсыг 1990 онд оруулсан юм. ХАЁТ нь дотроо буцалтгүй тусламж, хөнгөлөлттэй зээл, техникийн хамтын ажиллагаа гэсэн 3 төрөлтэй. Японы ХАЁТ-ийн хүрээнд хэрэгжүүлсэн төсөл, хөтөлбөрүүд нь Монгол Улс зах зээлийн эдийн засагт шилжих үеийн хүндрэлийг даван туулах, эдийн засгийн бүтцийн өөрчлөлт хийх, нийгмийн олон талын асуудлыг шийдвэрлэх, хүний нөөцийг хөгжүүлэх зэрэг өргөн цар хүрээтэй асуудлыг шийдвэрлэхэд ихээхэн хувь нэмэр оруулсаар ирсэн. Тусламжийн төслүүд хэрэгжсэнээр манай улс бүтцийн суурь өөрчлөлтөө 
амжилттай хийж, эдийн засгийн хүндрэлээс гарч, хөрөнгө оруулалт идэвхжиж, ядуурлыг бууруулж, ажлын байрыг нэмэгдүүлэн, ард түмний аж амьдрал дээшлэхэд маш чухал үүрэг гүйцэтгэсэн билээ.

2014 оны байдлаар Япон улсаас Монгол Улсад жилд дунджаар 45-50 сая ам.долларын хөнгөлөлтэй зээл, 30-35 сая ам.долларын буцалтгүй тусламж, 10 гаруй сая ам.долларын техникийн хамтын ажиллагааны тусламж олгосоор ирсэн нь манай улсад үзүүлж буй гадаадын зээл тусламжийн гуравны нэгийг эзэлж байв. ${ }^{1}$

Японы Засгийн газраас манай улсад үзүүлсэн тусламж нь мал аж ахуй, газар тариалан, аж үйлдвэр (үүний дотор уул уурхай, эрчим хүч, дулааны үйлдвэрлэл, усан хангамж, хог хаягдлын үйлчилгээ), барилга, холбоо мэдээлэл, тээвэр ложистик, нийтийн үйлчилгээ, худалдаа, байгаль орчны хамгаалал зэрэг манай эдийн засаг, дэд бүтцийн бараг бүх салбарыг хамарч байна.

2000 оноос 2015 оны хооронд 65 тэрбум 985 сая иэний буцалтгүй тусламж, 95 тэрбум 957 сая иэний хөнгөлөлттэй зээл, 28 тэрбум 662 сая иэний техникийн хамтын ажиллагааны тусламжийг ${ }^{2}$ өгчээ.

Япон улсаас Монгол Улсад суугаа Элчин сайдын яамны сайтад Япон улсаас Монголд өгөх ХАЁТ-ийн чиглэлийн талаар бичихдээ, "Монгол Улсын эдийн засаг Япон зэрэг хандивлагч орнуудын дэмжлэгтэйгээр, мөн урд хөрш болох БНХАУ-ын эдийн засгийн хөгжлийн нөлөө болон дотоодын уул уурхайн салбарын хөгжлийг даган хурдацтай өсөж байна. Гэвч Монгол Улсын эдийн засаг нь эрдэс баялгийн экспортоос ихээхэн хамааралтай тул цаашид аж үйлдвэрийг төрөлжүүлэх асуудал тулгамдаж байна. Мөн эдийн засгийн тогтвортой өсөлтийг бий болгоход макро эдийн засгийн тогтвортой менежмент шаардагдаж байна. Нөгөө талаар, эдийн засгийн хурдацтай өсөлтийн үр шим нийгмийн ядуу давхаргад хангалттай хүрэхгүй байгаа тул ядуурал ба ажилгүйдлийн түвшин урьдын адил өндөр, ялангуяа залуу ажиллах хүчнийг ажлын байраар хангах асуудал тулгамдсан хэвээр байна. Нийслэл Улаанбаатар хотод

1 Монгол Улсаас Япон улсад суугаа элчин сайдын яамны сайт, “Худалдаа, эдийн засгийн харилцаa" http://www.tokyo.embassy.mn/index.php?moduls=14

2 Япон улсаас Монгол Улсад суугаа элчин сайдын яамны сайт, “Япон улсаас Монгол Улсад үзүүлсэн зээл тусламжийн нэгдсэн дүн”, http://www.mn.emb-japan.go.jp/mn/ bi_relation/econ_coop/econcoop-list.html 
хүн ам хэт төвлөрч буйгаас үүдэн суурь дэд бүтцийн дутмаг байдал, орчны бохирдол зэрэг асуудлууд урган гарсаар байна. Дээрх нөхцөл байдлыг харгалзан Япон улсын Засгийн газрын зүгээс Монгол Улсын эдийн засгийн өсөлтийн үр шимийг нийгмийн бүх давхаргад жигд хүртээмжтэй болгох, Мянганы хөгжлийн зорилт зэрэг хөгжлийн цогц бодлого зорилтыг хэрэгжүүлэх, эдийн засгийн тогтвортой, тэнцвэртэй өсөлтийг бий болгоход чиглэсэн Монгол Улсын Засгийн газрын үйл ажиллагааг дэмжих чиглэлээр 1. Уул уурхайн тогтвортой хөгжлийг хангах, засаглалыг бэхжүүлэх, 2. Бүх хүнд өгөөжтэй өсөлтийг бэхжүүлэх, 3. Улаанбаатар хотын чадавхийг бэхжүүлэх гэсэн гурван үндсэн чиглэлд ХАЁТ-аа чиглүүлж байна"з гэжээ.

Сүүлийн үед Монгол Улсын эдийн засаг тэлэн өргөжихийн хэрээр Японы Улсын ХАЁТ-ийн хэлбэр, агуулгад өөрчлөлт гарч байна. Монгол Улсын эдийн засаг эрчимтэй өссөнөөр Монголын нэг хүнд оногдох ДНБ-ий хэмжээ Дэлхийн банкнаас тогтоосон IDA стандартаас даваад байна. Тийм учраас цаашид Япон улсаас Монгол Улсад үзүүлэх эдийн засгийн дэмжлэг дотор буцалтгүй тусламжийн хэмжээ ихээхэн багасах хандлагатай байгаа бөгөөд үүний оронд бага хүүтэй, урт хугацааны иэний хөнгөлөлттэй зээлийн хамтын ажиллагаа өргөжих хандлагатай байна.

\section{Монгол, Японы худалдааны харилцааны өнөөгийн байдал}

Монгол Улсын Засгийн газрын тэргүүн Д.Содном 1990 оны 2 дугаар сард Япон улсад айлчлах үед хоёр улсын хооронд худалдааны хэлэлцээр байгуулсан юм. Японы талын статистикийн мэдээнээс үзвэл, Монгол Японы хооронд хийгдсэн худалдааны дүн 2014 оны байдлаар ойролцоогоор 36 тэрбум 400 сая иэн байжээ. Үүнээс Японоос Монголд гаргасан экспортын барааны дүн 34 тэрбум 570 сая орчим иэн байна. Харин Монголоос Японд оруулсан импортын барааны дүн 1 тэрбум 810 сая орчим иэн байна. ${ }^{4}$ Японы Сангийн

3 “Япон-Монголын хөгжлийн хамтын ажиллагааны тухай”, http://www.mn.embjapan.go.jp/mn/bi_relation/econ_coop/econcoop-guideline.html

4 『最近のモンゴル情勢と日・・モンゴル関係』平成28年1月、(“Монголын сүүлийн үеийн нөхцөл байдал ба Япон, Монголын харилцаа”, 2016 он, 1 дүгээр 
яамны статистикийн мэдээнээс үзвэл, Монгол Японы хоорондын худалдааны дүн 2015 оны байдлаар 36 тэрбум 926 сая орчим иэн болжээ. Үүнд Монголоос Япон руу хийгдсэн экспортын дүн 6 тэрбум 574 сая орчим иэн болсон ба Японоос Монгол руу хийгдсэн импортын дүн 30 тэрбум 351 сая орчим иэн болсон байна. Японоос Монгол руу экспортолдог гол бараа бүтээгдэхүүн нь автомашин, ердийн техник хэрэгсэл, барилгын техник хэрэгсэл, уул уурхайн техник хэрэгсэл юм. Мөн сүүлийн үед хүнс, эрүүл мэнд, гоо сайхны бүтээгдэхүүн ч оруулж байна. Монголоос Япон руу экспортолдог гол бараа бүтээгдэхүүн нь ашигт малтмал (нүүрс, хайлуур жонш), ноос ноолууран бүтээгдэхүүн ажээ. ${ }^{5}$ Мөн хүнс (давс, чацаргана, цагаан идээ) экспортолж байна.

2000 оноос хойш Япон улстай хийсэн худалдааны дүнг он тус бүрээр үзүүлвэл дараах байдалтай байна.

Хүснэгт 1. 2000-2015 онд Япон улстай хийсэн худалдааны дүн ${ }^{6}$ /сая ам.доллар/

\begin{tabular}{cccc}
\hline онууд & Нийт эргэлт & Экспорт & Импорт \\
\hline 2000 & 81.4 & 8.1 & 73.3 \\
\hline 2001 & 71.7 & 15.7 & 56.0 \\
\hline 2002 & 49.1 & 6.3 & 42.8 \\
\hline 2003 & 71.9 & 8.5 & 63.4 \\
\hline 2004 & 108.4 & 33.4 & 75.0 \\
\hline 2005 & 81.3 & 5.8 & 75.5 \\
\hline 2006 & 104.7 & 7.1 & 97.6 \\
\hline 2007 & 155.3 & 15.1 & 140.2 \\
\hline 2008 & 266.1 & 27.6 & 238.5 \\
\hline
\end{tabular}

cap) http://www.mofa.go.jp/mofaj/files/000047765.pdf

5 『モンゴル国、基礎データ』、(“Монгол Улс, үндсэн мэдээлэл”), http://www. mofa.go.jp/mofaj/area/mongolia/data.html

6 “Монгол Улсын статистикийн эмхэтгэл" 2000-2015 


\begin{tabular}{cccc}
\hline онууд & Нийт эргэлт & Экспорт & Импорт \\
\hline 2009 & 101.6 & 4.6 & 97.0 \\
\hline 2010 & 199.2 & 2.7 & 196.5 \\
\hline 2011 & 501.2 & 11.0 & 490.2 \\
\hline 2012 & 507.2 & 5.6 & 501.6 \\
\hline 2013 & 454.7 & 10.5 & 444.2 \\
\hline 2014 & 392.2 & 24.5 & 367.8 \\
\hline 2015 & 295.0 & 20.3 & 274.6 \\
\hline
\end{tabular}

Эх сурвалж: "Монгол Улсын статистикийн эмхэтгэл” 2000-2015

Дээрх хүснэгтээс харвал худалдааны алдагдал их байна. Япон руу гаргадаг экспортын барааны хэмжээ бага, Японоос оруулдаг импортын барааны хэмжээ хэд дахин их байна. Энэ алдагдлыг багасгах шаардлагатай. Ингэхийн тулд дотоодын үйлдвэрлэлээ нэмэгдүүлж, экспортын барааны хэмжээг нэмэх хэрэгтэй юм. Мөн Японы техник технологийг нэвтрүүлж, бараа бүтээгдэхүүнийхээ чанарыг сайжруулан, Японы зах зээлд борлогдох түвшний бүтээгдэхүүн үйлдвэрлэх хэрэгтэй гэж үзэж байна.

Монгол, Японы хооронд ЕРА байгуулах хэлэлцээг 2012 оны 6 дугаар сараас 2014 оны 7 дугаар сар хүртэл нийт 7 удаа хийж, зарчмын тохиролцоонд хүрсэн. “Эдийн засгийн түншлэлийн тухай Монгол Улс, Япон улсын хоорондын хэлэлцээр"-т хоёр орны Ерөнхий сайд нар 2015 оны 2 дугаар сарын 10-нд гарын үсэг зурсан билээ. Энэ хэлэлцээр нь 2016 оны 6 дугаар сарын 7-нд хүчин төгөлдөр болсон юм. Хэлэлцээр нь дотроо 13-14 чиглэлтэй, худалдааны тариф, саад болоод бусад тотгорыг арилгах, хөрөнгө оруулалтын орчинг сайжруулах, оюуны өмч, гаалийн горим, хамтын ажиллагаа, цахим худалдаа гэх мэт өргөн цар хүрээтэй хамтын ажиллагааны асуудлуудыг хамарч байна. Бизнес эрхлэгчдэд очих шууд нөлөөлөл нь барааны гаалийн татварыг чөлөөлөх явдал юм. Дэлхийн худалдааны байгууллагад бүртгэгдсэн, гаалийн кодлолоор 9000 орчим барааны татварыг чөлөөлж байгаа бөгөөд хоёр орны бизнес эрхлэгчдийн экспорт, импортын зардал буурах 
үр дүн гарна гэж хэлж болно. Монгол Улс юуны түрүүнд Японы өндөр технологи, техник, менежмент, ажлын арга барилыг эдийн засагтаа нэвтрүүлэхийг сонирхож байгаа бол Япон улс нүүрс, зэс, цайр болон бусад эрдсийн түүхий эд, монгол малын мах, ноос зэрэг ХАА-н бүтээгдэхүүнийг худалдан авахыг сонирхож байгаа билээ. Хоёр тал хөдөө аж ахуй, аж үйлдвэр, дэд бүтэц, уул уурхай, аялал жуулчлалын салбарт өргөн хүрээтэй хамтын ажиллагааг хөгжүүлэх, Улаанбаатар болон аймгуудад эмнэлгийн сургалт-оношлогооны төвүүд, нефть боловсруулах үйлдвэр, Хөшигтийн хөндийн олон улсын нисэх буудал байгуулах, Тавантолгойн зүүн чиглэлийн төмөр зам зэрэг томоохон төслүүдийг хэрэгжүүлэхэд санхүу, техникийн талаар хамтран ажиллах юм. “Эдийн засгийн түншлэлийн хэлэлцээр” хүчин төгөлдөр болсны дараа байгуулагдсан Монгол Улсын Засгийн газар хэлэлцээрийг үргэлжлүүлэн хэрэгжүүлэх талаар түншлэгч талтай идэвхитэй хамтран ажиллахаа мэдэгдсэн бөгөөд Монгол Улсын Ерөнхий сайд Ж.Эрдэнэбатын 2016 оны 10 дугаар сард Япон улсад хийсэн айлчлалын үеэр хоёр тал хөдөө аж ахуй, хүрээлэн буй орчин, сэргээгдэх эрчим хүчний үйлдвэрлэлд хамтын ажиллагааг үргэлжүүлэх, 2015-2017 онд хэрэгжиж байгаa Дунд хугацааны хөтөлбөрийг цаашид үргэлжлүүлэх хамтын ажиллагааны шинэ төлөвлөгөө боловсруулахаар тохиролцсон билээ.

\section{Японоос Монголд оруулсан шууд хөрөнгө оруулалт}

Монголд оруулсан Японы шууд хөрөнгө оруулалт өнөөгийн байдлаар манай хөнгөн үйлдвэр, соёл урлаг, боловсрол, шинжлэх ухаан, хэвлэл, харилцаа холбоо, тээвэр, худалдаа, нийтийн хоол, геологи уул уурхайн эрэл хайгуул, судалгаа, олборлолт, мал аж ахуйн гаралтай түүхий эдийн боловсруулалт, инженерийн барилга байгууламж, барилгын материалын үйлдвэрлэл, хүнсний бүтээгдэхүүний үйлдвэрлэл, аялал жуулчлал, банк санхүүгийн үйл ажиллагаа, эрүүл мэнд, гоо сайхны үйлчилгээ, худалдаа, нийтийн хоол, ахуйн үйлчилгээ, мал аж ахуй, газар тариалан, эрчим хүч, мебель модон эдлэл, цахилгаан хэрэгслийн үйлдвэрлэлийн салбарт тодорхой хэмжээний хөрөнгө оруулалт хийжээ. Японы хөрөнгө 
оруулалтын дийлэнх хувь буюу $48 \%$ нь худалдаа, нийтийн хоол, $18 \%$ нь хөнгөн үйлдвэр, 6\% мэдээлэл, холбооны технологи, 7.3\% нь банк санхүүгийн салбарт ногдож байна. Харин геологи, уул уурхайн эрэл хайгуул, олборлолтын салбарт $2.7 \%$, мал аж ахуйн гаралтай түүхий эдийн боловсруулалтын салбарт $1.1 \%$ ногдож байна. ${ }^{7}$

1990-2016 он хүртэл Монголд орсон Японы хөрөнгө оруулалтын нийт хэмжээ 262 сая ам.доллар байна. Энэ нь Монголд хөрөнгө оруулсан орнуудын дотор 11 дүгээр байранд жагсаж байна. 2014 оны 10 дугаар сарын 1-ний байдлаар Монголд салбараа нээсэн Японы 31 компани, Монголын компанитай хамтарсан 194 компани байсан ба эдгээрийн ихэнх нь жижиг дунд аж ахуйн нэгжүүд байжээ. Хоёр орны хооронд байгуулагдсан Япон, Монголын хөрөнгө оруулалтын хэлэлцээр 2002 оны 3 дугаар сараас хэрэгжсэн юм. ${ }^{8}$

Монголд орох Японы хөрөнгө оруулалтын хэмжээ, компанийн тоо өнөөдрийг хүртэл буурч ирсэн Үзүүлэлттэй байна. Үүнд Монголын улс төрийн тогтворгүй байдал, хууль эрх зүйн орчин, авлигал, хүнд суртал, төрийн албан хаагчдын ёс зүйгүй байдал нөлөөлжээ. ${ }^{9}$ Цаашид Японы хөрөнгө оруулалтын хэмжээ, компанийн тоог нэмэгдүүлэхийн тулд улс төрөө тогтвортой байлгаж, хууль эрх зүйн орчноо сайжруулан, авлигал, хүнд суртал, төрийн албан хаагчдынхаа ёс зүйгүй байдлыг арилгах шаардлагатай байна.

\section{Дүгнэлт}

Япон улсын Засгийн газар Монгол Улсад 2000-2015 он хүртэлх хугацаанд нийтдээ 190 тэрбум 604 сая иэний тусламж, хөнгөлөлтэй зээл олгосон байна. Өөрөөр хэлбэл, 65 тэрбум 985 сая иэний буцалтгүй тусламж, 95 тэрбум 957 сая иэний хөнгөлөлттэй зээл, 28 тэрбум 662 сая иэний техникийн хамтын ажиллагааны

7 “Монгол Японы худалдаа, эдийн засгийн харилцааны товч лавлах”, http://tokyo.mfa. gov.mn/index.php?option $=$ com

8 『最近のモンゴル情勢と日・モンゴル関係』平成28年1月、(“Монголын сүүлийн үеийн нөхцөл байдал ба Япон, Монголын харилцаа”, 2016 он, 1 дүгээр cap) http://www.mofa.go.jp/mofaj/files/000047765.pdf

9 “Японы хөрөнгө оруулалт, зээл, тусламж, түүний үр ашиг” ШУА-ийн ОУСХ, УБ, 2004, 56 дугаар тал 
тусламж үзүүлжээ. Уг тусламж нь Монголын нийгэм, эдийн засгийн хүндрэлийг даван туулах, зах зээлийн эдийн засагт шилжих, Монгол Улсын шинэ хөгжлийн суурийг тавихад үлэмж хувь нэмэр болсон билээ.

Монгол, Японы Стратегийн түншлэлийн дунд хугацааны хөтөлбөр 2013 оноос амжилттай хэрэгжиж эхэлсэн бөгөөд эхний хэсэг энэ онд дууссан юм. Хөтөлбөрийн хүрээнд хэрэгжүүлсэн хамгийн том ажил бол Эдийн засгийн түншлэлийн хэлэлцээрийг хүчин төгөлдөр болгон хэрэгжүүлж эхэлсэн явдал зүй ёсоор орно. Өнгөрсөн оны 6 дугаар сард Монгол, Японы Эдийн засгийн түншлэлийн хэлэлцээр хүчин төгөлдөр болж, хэрэгжүүлж эхэлснээс энэ оны хоёрдугаар сарын байдлаар нийт 320 ширхэг, нийт 8.2 сая ам.долларын үнэ бүхий Монголд үйлдвэрлэсэн бүтээгдэхүүнийг гаалийн тарифын хөнгөлттэй нөхцөлөөр Япон улсад экспортлож, 300 гаруй бүтээгдэхүүнд гарал үүслийн гэрчилгээ олгоод буй аж. Энэ бүхнээс үзэхэд манай засаг төр хууль эрх зүйн орчноо тогтворжуулж, хэлсэндээ хүрч, итгэл олж, хувийн хэвшлийн бизнес эрхлэгчдийг бодлогоор дэмжвэл өрсөлдөх чадвартай, стандартын шаардлага хангасан бараа бүтээгдэхүүнийг Японы зах зээлд гаргах, хөрөнгө оруулалт татах, хамтарсан үйлдвэрлэл эрхлэх өргөн боломжтой болохыг харуулж байна.

Хоёр орны худалдаа, эдийн засгийн харилцаа, хамтын ажиллагааг улам бүр тэлэн өргөжүүлэхэд энэ оны эхний хагасаас хүчин төгөлдөр болсон Монгол, Японы Стратегийн түншлэлийн дунд хугацааны 2017-2021 он хүртэлх хамтын ажиллагааны хөтөлбөр жинтэй хувь нэмэр оруулах нь дамжиггүй.

\section{Ном зүй:}

1. "Японы хөрөнгө оруулалт, зээл, тусламж, түҮний үр ашиг” ШУА-ийн ОУСХ, УБ, 2004

2. “Монгол Улсын статистикийн эмхэтгэл” 2000-2015

3. Монгол Улсаас Япон улсад суугаа элчин сайдын яамны сайт, “Худалдаа, эдийн засгийн харилцаa” "http://www.tokyo.embassy. mn/index.php?moduls $=14$ 
4. Япон улсаас Монгол Улсад суугаа элчин сайдын яамны сайт, "Япон улсаас Монгол Улсад үзүүлсэн зээл тусламжийн нэгдсэн дүн”, http://www.mn.emb-japan.go.jp/mn/bi_relation/ econ_coop/econcoop-list.html

5. "Япон-Монгольн хөгжлийн хамтын ажиллагааны тухай", http://www.mn.emb-japan.go.jp/mn/bi_relation/econ_coop/ econcoop-guideline.html

6. “Одоо хэрэгжиж буй болон хэрэгжүүлэхээр төлөвлөж буй техникийн хамтын ажсиллагааны төслүүд" http://www. mn.emb-japan.go.jp/mn/bi_relation/econ_coop/TC.mon.pdf

7. "Монгол Японь худалдаа, эдийн засгийн харилцааны товч лавлах", http://tokyo.mfa.gov.mn/index.php?option=com

8.『モンゴル国、基礎データ』、( “Монгол Улс, мэдээлэл”), http://www.mofa.go.jp/mofaj/area/mongolia/data.html

9.『最近のモンゴル情勢と日・モンゴル関係』平成 28 年 1月、("Монгольын сүүлийн уеийн нөхиөл байдал ба Япон, Монголын харилиаа”, 2016 он, 1 дүгээр сар) http://www.mofa. go.jp/mofaj/files/000047765.pdf

10.『最近のモンゴル情勢と日・モンゴル関係』平成 28 年 1月、("Монгольин сүүлийн уешйн нөхиөл байдал ба Япон, Монголын харилцаа”, 2016 он, 1 дүгээр сар) http://www.mofa. go.jp/mofaj/area/mongolia/data.html 


\section{CURRENT ISSUES OF \\ TRADE AND ECONOMIC RELATIONS \\ BETWEEN MONGOLIA AND JAPAN}

\section{M.Bolormaa}

In this article, it has been aimed to explore the current state of trade and economic relations and collaboration between Mongolia and Japan, under the framework of Official Development Assistance (ODA), trade, investment and Economic Partnership Agreement (EPA), from the beginning of the new millennium, in other words, from early 2000s.

Keywords: Official Development Assistance (ODA), trade, investment, Economic Partnership Agreement (EPA) 